\title{
INFLUENCE OF THYME AND JUNIPER ON THE MICROBIOLOGICAL PROPERTIES OF PORK BRISKET
}

\author{
Uliana Drachuk \\ Department of Technology of meat, oil and fat products \\ Stepan Gzhytskyi National University of Veterinary Medicine and Biotechnologies \\ 50 Pekarska str., Lviv, Ukraine, 79010 \\ ul.drachuk@gmail.com \\ Iryna Simonova \\ Department of technology of meat, oil and fat products \\ Stepan Gzhytskyi National University of Veterinary Medicine and Biotechnologies \\ 50 Pekarska str., Lviv, Ukraine, 79010 \\ ira.markovuch@gmail.com \\ Bohdan Halukh \\ Department of Technology of meat, oil and fat products \\ Stepan Gzhytskyi National University of Veterinary Medicine and Biotechnologies \\ 50 Pekarska str., Lviv, Ukraine, 79010 \\ b.halukh@gmail.com \\ Iryna Basarab \\ Department of technology of meat, oil and fat products \\ Stepan Gzhytskyi National University of Veterinary Medicine and Biotechnologies \\ 50 Pekarska str., Lviv, Ukraine, 79010 \\ iryna.basarab@gmail.com \\ Iryna Romashko \\ Department of Technology of meat, oil and fat products \\ Stepan Gzhytskyi National University of Veterinary Medicine and Biotechnologies \\ 50 Pekarska str., Lviv, Ukraine, 79010 \\ mysh@ukr.net
}

\begin{abstract}
The aim of the work is to determine an influence of non-traditional mixtures of spicy-aromatic plants of thyme and juniper, their essential oils and alcohol extracts on the course of microbiological processes in pork brisket. Pork brisket was an experimental sample. It was added with black pepper, thyme and juniper, in the dry condition, as essential oils and alcohol extracts. Pork brisket, added with dry plants, essential oils, extracts of black and fragrant pepper, was taken as a control. According to the microbiological studies, it was established, that an exceed of the standard index of the content of mesophilic-aerobic and facultative anaerobic microorganisms (more than $1,0 \times 103 \mathrm{~g} / \mathrm{CCU}$ ) takes place in brisket samples with dry black pepper. And also in samples with thyme and juniper in ratios 0,9:0,7:0,2 and 0,9:0,6:0,3. An exceed of nMAFAM index is also fixed in experiments using essential oils of these spices. It was established, that after $80 \mathrm{~min}$ of the experiment, these mixtures remain resistant to spoilage by 20 min longer comparing with using dry black and fragrant pepper. Most intense antibacterial properties relative to the development of microorganisms were observed in experimental samples. It is noticeable in a sample with using dry comminuted spices thyme and juniper in ratios 0,9:0,8:0,1. The use of spicy-aromatic plants of thyme and juniper allow to increase the storage term of ready products.
\end{abstract}

Keywords: dry mixtures of black pepper, essential oils of thyme, alcohol extracts of juniper.

DOI: $10.21303 / 2504-5695.2018 .00785$

(C) Uliana Drachuk, Iryna Simonova, Bohdan Halukh, Iryna Basarab, Iryna Romashko

\section{Introduction}

Different supplements of the vegetable and animal origin, with a high food value, functional properties and able to improve or stabilize the quality of ready products, are used in modern technologies of sausages production alongside with base raw materials. 
Complex spicy-aromatic mixtures became an unalienable part of recipes and technological process of sausages production. It gives a possibility to make products of the stable quality and to widen their assortment. The use of spicy-aromatic plants allows to improve an outlook and sanitary-hygienic quality parameters of meat products. Due to substances, contained in them, spoilage processes of products stop due to their destructive effect on the pathogenic microflora [1].

The study was conducted as to the use of elder, thorn, ashberry extracts in food industry for revealing their braking effect on creation of free radicals. It was established, that plants contain the high level of natural antioxidants - anthocyans and polyphenols [2].

The studies proved that aromatic herbs of rosemary, thyme and lavender and their essential oils have antioxidant properties and prolong the storage life of products [3]. There were studied antioxidant and antimicrobial properties of savory essential oil. The effectiveness of its use at food products manufacturing was proved [4]. The surface part of savory is used as a bactericidal, spasmolytic, diaphoretic, antiseptic means. It is used in food industry at pickling of cucumber and tomatoes, as an aromatic spice for soups, meat, mushroom, fish dishes and salads. It is used in Bulgaria as a spice in the mixture of salt, paprika, black pepper and fenugreek [5]. Essential oils gained the wide use together with spicy extracts. The results of the conducted studies proved that essential oils of rosemary and sage more intensely inhibit oxidizing spoilage of liver paste than a synthetic antioxidant [6]. Essential oils of balm are also characterized by positive antioxidant properties. Antioxidant properties of infusions of spicy herbs were studied [7].

The traditional recipe of sausage products includes black and fragrant pepper. Black pepper fruits contain essential oil up to $2,5 \%$, its main part is formed by pinnen, limonene and phellandrene, it also contains choline and acetylcholine, 5-9\% of piperine. Active substances, included in black pepper, stimulate the activity of the thyroid gland and increase oxygen consumption by tissues [8]. Black pepper contains 3,5\% of essential oil, which main component is eugenol, cineol, caryophillene and phellandrene. Fruits and leaves of black pepper are a source of essential oil, used in medicine, especially in stomatological practice as an antiseptic means. Pepper also improves the stomach work, it is useful at wind [9].

Thyme is used in food industry for aromatization of sausages, cheeses, sauces, vinegar, confectionary products, for making liqueurs, at pickling vegetables, as a spice for salads, meat and fish dishes. New sprouts contain vitamin C (54,5 mg \%), acids, mineral salts, protein substances. Dry thyme is used in many cookeries of the world as a spice for meat, vegetable and fish dishes [10]. Juniper fruits have a sweet and tart smack. Juniper fruits are used first of all for preparing meat of wild animals. This spice is perfectly combined with onion, garlic, mint, marjoram and is often used for producing marinades, in the technology of sausage products. Juniper cone-berries contain carbohydrates (40\%), wax, resins, tanning and dyeing substances, essential oil (2\%), organic acids (apple, vinegar, formic), macro- and microelements; aluminium, copper, iron, manganese and so on [11].

The aim of the work is to determine the influence of mixtures of spicy-aromatic plants of thyme and juniper on the course of microbiological processes in pork brisket. It allows to fix the presence and development of microorganisms at storage that influences the storage life increase.

\section{Materials and Methods}

Black and fragrant comminuted peppers, thyme and juniper of TM "ECO", PE "Edel", Ukraine, were used for the study. Essential oils of black and fragrant pepper, thyme and juniper were produced by the method of distillation with water steam. Vegetable raw materials were placed in a distiller. Then steam is removed from a stand of the distiller, and essential oils are mixed with steam. This volatile substance is transformed in water by condensation. Essential oil is extracted on its surface, then is separated from it. Alcohol extracts of black and fragrant pepper, thyme and juniper were produced by extracting. Ethanol was used as an extragent. The process includes preparation of raw materials and extragent, getting of an extract, purification of an extract. Dry comminuted aforesaid plants, their essential oils and alcohol extracts are added to pork brisket. Pork brisket, containing black and fragrant pepper in ratios 1:0,9 mg/1000 g was taken as a control. Experimental samples of pork brisket were added with dry black pepper : thyme : juniper in ratios 
(mg/1000 g): 0,9:0,8:0,1 0,9:0,7:0,2 and 0,9:0,6:0,3. The recipes of control and experimental samples are presented in Table 1.

Table 1

Recipes of control and experimental samples

\begin{tabular}{|c|c|c|c|c|c|c|c|c|c|c|c|c|}
\hline \multirow[b]{2}{*}{ Name of the recipe component } & \multicolumn{12}{|c|}{ Name of the experimental sample } \\
\hline & 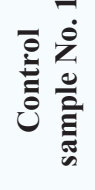 & 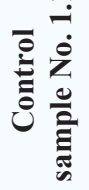 & 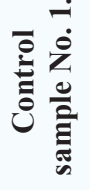 & 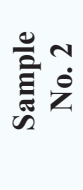 & 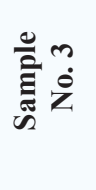 & 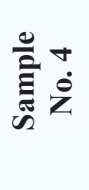 & 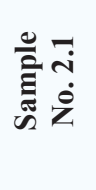 & 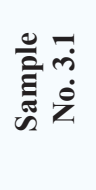 & 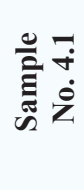 & 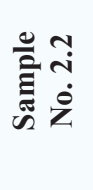 & 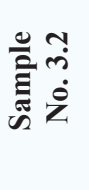 & 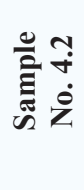 \\
\hline Pork brisket, $g$ & 1000 & 1000 & 1000 & 1000 & 1000 & 1000 & 1000 & 1000 & - & - & - & - \\
\hline Black pepper, mg/ $1000 \mathrm{~g}$ & 1 & - & - & 0,9 & 0,9 & 0,9 & - & - & - & - & - & - \\
\hline Fragrant pepper mg / $1000 \mathrm{~g}$ & 0,9 & - & - & - & - & - & - & - & - & - & - & - \\
\hline Thyme mg/1000 g & - & - & - & 0,8 & 0,7 & 0,6 & - & - & - & - & - & - \\
\hline Juniper mg /1000 g & - & - & - & 0,1 & 0,2 & 0,3 & - & - & - & - & - & - \\
\hline $\begin{array}{l}\text { Essential oils of black pepper, } \\
\mathrm{ml} / 1000 \mathrm{~g}\end{array}$ & - & 1 & - & - & - & - & 0,9 & 0,9 & 0,9 & - & - & - \\
\hline $\begin{array}{l}\text { Essential oils of fragrant pepper } \\
\mathrm{ml} / 1000 \mathrm{~g}\end{array}$ & - & 0,9 & - & - & - & - & - & - & - & - & - & - \\
\hline Essential oils of thyme $\mathrm{ml} / 1000 \mathrm{~g}$ & - & - & - & - & - & - & 0,8 & 0,7 & 0,6 & - & - & - \\
\hline Essential oils of juniper $\mathrm{ml} / 1000 \mathrm{~g}$ & - & - & - & - & - & - & 0,1 & 0,2 & 0,3 & - & - & - \\
\hline $\begin{array}{l}\text { Alcohol extracts of black pepper, } \\
\qquad \mathrm{ml} / / 1000 \mathrm{~g}\end{array}$ & - & - & 1 & - & - & - & - & - & - & 0,9 & 0,9 & 0,9 \\
\hline $\begin{array}{l}\text { Alcohol extracts essential oils of } \\
\text { fragrant pepper } \mathrm{ml} / 1000 \mathrm{~g}\end{array}$ & - & - & 0,9 & - & - & - & - & - & - & - & - & - \\
\hline $\begin{array}{l}\text { Alcohol extracts essential oils of } \\
\text { thyme } \mathrm{ml} / 1000 \mathrm{~g}\end{array}$ & - & - & - & - & - & - & - & - & - & 0,8 & 0,7 & 0,6 \\
\hline $\begin{array}{l}\text { Alcohol extracts essential oils of } \\
\text { juniper } \mathrm{ml} / 1000 \mathrm{~g}\end{array}$ & - & - & - & - & - & - & - & - & - & 0,1 & 0,2 & 0,3 \\
\hline
\end{tabular}

The method of determination of the number of mesophilic aerobic and facultative-anaerobic microorganisms (nMAFAM) is realized by inoculation in a nutritive medium, incubation of inoculations, calculation of all grown colonies. A tenfold solution is produced from a batch of the product. Inoculation is made from correspondent solutions in two parallel Petri dishes and poured by one of agarized mediums. Inoculations are incubated at temperature $30{ }^{\circ} \mathrm{C}$ for 72 hours, then colonies are calculated and the correspondence for each type of products by this parameter is determined.

\section{1. Experimental procedures}

Pork brisket is comminuted in pieces, added with dry mixtures of spicy-aromatic plants, extracts and essential oils. Experimental samples were selected for the further studies. Processes of fat oxidation were realized by subjecting experimental samples to the effect of high temperatures (t $100 \pm 2{ }^{\circ} \mathrm{C}$ ) with the air access during $120 \mathrm{~min}$. For revealing the influence of spicy-aromatic plants, their essential oils and extracts on the development of microorganisms, there were selected samples for the microbiological studies. Namely: fresh brisket and spoiled samples. Control ones with using dry comminuted spices, their extracts at $60 \mathrm{~min}$ of the experiment, essential oils - at 60 and $80 \mathrm{~min}$ of it. Experimental ones - with using dry spices, their essential oils after 60-120 min 
of the experiment, extracts - after 60-80 min of it. Samples were inoculated for determining the number of mesophilic aerobic and facultative-anaerobic microorganisms, CCU, in $\mathrm{g}$ of the product. nMAFAM must not exceed 1,0×103, according to SSU 4668:2006 "Boiled, smoked-boiled, smokedbaked, baked, fried, raw-smoked pork products".

\section{Results}

nMAFAM in the control sample No.1 with using dry comminuted thyme and juniper grew twice after $60 \mathrm{~min}$ of the experiment, comparing with the initial value that was $2,5 \times 10^{2} \mathrm{CCU} / \mathrm{g}$, control sample No.1.1 with using their essential oils at $60 \mathrm{~min}-1,1 \times 10^{3}$, and at $80 \mathrm{~min}-9,8 \times 10^{3}$, that demonstrates the intense development of microorganisms not only after spoiling samples, but also when the value of their peroxide and benzidine numbers are at the stage of doubtful freshness, control sample No.1.2, in which black and fragrant pepper extracts were used - reached maximal value $4,7 \times 10^{4} \mathrm{CCU} / \mathrm{g}$ after $60 \mathrm{~min}$ that exceeds the previous samples essentially (Table 2).

Table 2

Comparative characteristics of nMAFAM CCU/g in experimental samples of brisket with using spicyaromatic plants

\begin{tabular}{lcccc}
\hline & \multicolumn{3}{c}{ nMAFAM, CCU/g } \\
\cline { 2 - 5 } Name of sample & 0 min & $\mathbf{6 0}$ min & $\mathbf{8 0 ~ m i n ~}$ & $\mathbf{1 2 0}$ min \\
\hline Control Sample No. 1 - dry comminuted BP:FP1:0,9 mg/1000 g & $2,5 \times 10^{2}$ & $3,0 \times 10^{4}$ & - & - \\
Control Sample No. 1.1. - essential oils BP:FP 1:0,9 & $2,0 \times 10^{2}$ & $1,1 \times 10^{3}$ & $9,8 \times 10^{3}$ & - \\
Control Sample No. 1.2 - alcohol extract BP:FP 1:0,9 & $2,1 \times 10^{2}$ & $4,7 \times 10^{4}$ & - & - \\
Sample No. 2 - dry comminuted BP:T:J 0,9:0,8:0,1 & $2,3 \times 10^{2}$ & $6,0 \times 10^{2}$ & $9,9 \times 10^{2}$ & $2,0 \times 10^{4}$ \\
Sample No. 3 - dry comminuted BP:T:J 0,9:0,7:0,2 & $1,9 \times 10^{2}$ & $6,2 \times 10^{2}$ & $1,2 \times 10^{3}$ & $1,5 \times 10^{4}$ \\
Sample No. 4 - dry comminuted BP:T:J 0,9:0,6:0,3 & $2,8 \times 10^{2}$ & $7,2 \times 10^{2}$ & $1,1 \times 10^{3}$ & $2,8 \times 10^{4}$ \\
Sample No. 2.1 - essential oils BP:T:J 0,9:0,8:0,1 & $1,8 \times 10^{2}$ & $5,4 \times 10^{2}$ & $2,5 \times 10^{3}$ & $9,5 \times 10^{3}$ \\
Sample No. 3.1 - essential oils BP:T:J 0,9:0,7:0,2 & $3,0 \times 10^{2}$ & $6,9 \times 10^{2}$ & $2,7 \times 10^{3}$ & $1,1 \times 10^{4}$ \\
Sample No. 4.1 - essential oils BP:T:J 0,9:0,6:0,3 & $1,6 \times 10^{2}$ & $4,6 \times 10^{2}$ & $1,9 \times 10^{3}$ & $8,1 \times 10^{3}$ \\
Sample No. 2.2 - Alcohol extract BP:T:J 0,9:0,8:0,1 & $2,6 \times 10^{2}$ & $1,9 \times 10^{3}$ & $3,2 \times 10^{4}$ & - \\
Sample No. 3.2 - Alcohol extract BP:T:J 0,9:0,7:0,2 & $3,2 \times 10^{2}$ & $2,8 \times 10^{3}$ & $4,5 \times 10^{4}$
\end{tabular}

The use of black pepper, thyme and juniper, used in different ratios, manifests the antibacterial effect in brisket and stops the development of microorganisms more intensely than black and fragrant pepper. The difference is noticeable after $60 \mathrm{~min}$ of oxidizing the product. Whereas the growth of microorganisms exceeded the norm in the control sample, nMAFAM of the experimental

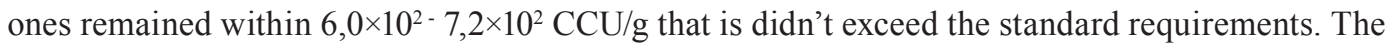
increase of the number of microorganisms that exceed the norm $1,0 \times 10^{3} \mathrm{CCU} / \mathrm{g}$ was revealed at $80 \mathrm{~min}$ (up to $1,2 \times 10^{3} \mathrm{CCU} / \mathrm{g}$, and at $120 \mathrm{~min}$, when accumulations of oxidation products in goods reached the maximal value - the number of microorganisms grew twice. A bit better microbiological indices are inherent to the brisket samples with using essential oils of black pepper and spicy-aromatic plants comparing with dry comminuted ones, but the nMAFAM value don't essentially differ from the previous ones - at $60 \mathrm{~min}$ it is within the norm (maximally to $6,9 \times 10^{2} \mathrm{CCU} / \mathrm{g}$ ), at $80 \mathrm{~min}$ - from $1,9 \times 10^{3}$ (Sample No. 4.1) to $2,7 \times 10^{3}$ (Sample No. 3.1), CCU/g. It must be noted that nMAFAM of the control sample with using essential oils of black and fragrant pepper exceeded the norm at $60 \mathrm{~min}-1,1 \times 10^{3} \mathrm{CCU} / \mathrm{g}$, at $80 \mathrm{~min}$ reached maximal value $9,8 \times 10^{3} \mathrm{CCU} / \mathrm{g}$, whereas when nMAFAM of the experimental samples was within $8,1 \times 10^{3}-1,1 \times 10^{4} \mathrm{CCU} / \mathrm{g}$. 
Alcohol extracts are ineffective in the fight against the development of microorganisms, because they manifest the weakest antibacterial effect. At using the alcohol extract of black and fragrant pepper there was observed the maximal value of nMAFAM 4,7×104 comparing with all studied samples. The development of microorganisms is noticeable in samples with using alcohol extracts of spicy-aromatic plants after $60 \mathrm{~min}$ of the experiment from $1,9 \times 10^{3}$ to $2,8 \times 10^{3} \mathrm{CCU} / \mathrm{g}$, the maximal value of the parameter was fixed after $80 \mathrm{~min}$-from $3,2 \times 10^{4}$ (sample No. 2.2) to $4,5 \times 10^{4}$ (sample No. 4.2) CCU/g, that is they have an advantage comparing with using alcohol extracts of black and fragrant peppers.

It must be noted, that at studying the total value of inoculation of the product by microorganism, it is impossible to determine what ratio of the used spicy-aromatic plants manifests maximal properties as to preserving the product quality, because initial indices of nMAFAM differ from each other. It may be caused by contamination of experimental samples from air, hands auxiliary materials at their selection for studies and preparation for inoculations. But it is proved, that black pepper, combined with thyme and juniper stops the development of microorganisms essentially better than the combination of black and fragrant pepper in any form (dried, comminuted, essential oils, extracts). The use of spicy-aromatic plants in the dry comminuted condition is not inferior to their essential oils as to the influence on the development of microorganisms, so their use in the offered condition is possible.

\section{Conclusions}

The use of both dry comminuted spicy-aromatic plants, based on black pepper, thyme and juniper, and their essential oils manifests the antibacterial activity much more intensely than black and fragrant pepper and stop the development of microorganisms twice. It is an advantage of the offered spices. A shortcoming is the fact that alcohol extracts of the experimental spices are ineffective, because it was established, that accumulation of oxidizing compounds and the development of microorganisms in experimental samples with their use is much faster comparing with other ones.

The studies are useful because the use of mixtures of the experimental spices in the dry comminuted condition guarantees the effective braking of animal fats spoilage processes. The use of mixtures of black pepper, thyme and juniper as new natural supplements is possible in the technology of sausage products for prolonging the storage term.

Further studies will be directed on investigating the influence of these spices on preservation of quality parameters of pastes of semi-smoked sausages.

\section{References}

[1] Rohlík, B.-A., Pipek, P., Pánek, J. (2013). Effect of natural antioxidants on the colour and lipid stability of paprika salami. Czech Journal of Food Sciences, 31 (4), 307-312. doi: https://doi.org/ $10.17221 / 327 / 2012$-cjfs

[2] Krektun, B. V. (2014). Antyoksydantni vlastyvosti plodiv roslyn rodyny rosaceae ta rodoxaceae ta yikh vykorystannia u skladi produktiv funktsionalnoho pryznachennia. Zbirnyk materialiv VI Vseukrainskoi naukvo-praktychna konferentsiya, 48-52.

[3] Gallego, M. G., Gordon, M. H., Segovia, F. J., Skowyra, M., Almajano, M. P. (2013). Antioxidant Properties of Three Aromatic Herbs (Rosemary, Thyme and Lavender) in Oil-in-Water Emulsions. Journal of the American Oil Chemists' Society, 90 (10), 1559-1568. doi: https://doi.org/10.1007/s11746-013-2303-3

[4] Bilenler, T., Gokbulut, I., Sislioglu, K., Karabulut, I. (2015). Antioxidant and antimicrobial properties of thyme essential oil encapsulated in zein particles. Flavour and Fragrance Journal, 30 (5), 392-398. doi: https://doi.org/10.1002/ffj.3254

[5] Satureja. Wikipedia. Available at: https://en.wikipedia.org/wiki/Satureja

[6] Stoilova, I. S., Wanner, J., Jirovetz, L., Trifonova, D., Krastev, L., Stoyanova, A. S., Krastanov, A. I. (2014). Chemical composition and antioxidant properties of juniper berry (Juniperus communis L.) essential oil. Bulgarian Journal of Agricultural Science, 20 (2).

[7] Höferl, M., Stoilova, I., Schmidt, E., Wanner, J., Jirovetz, L., Trifonova, D. et. al. (2014). Chemical Composition and Antioxidant Properties of Juniper Berry (Juniperus communis L.) Essential Oil. Action 
of the Essential Oil on the Antioxidant Protection of Saccharomyces cerevisiae Model Organism. Antioxidants, 3 (1), 81-98. doi: https://doi.org/10.3390/antiox3010081

[8] Tykhonenko, N. I., Kotov, A. G. (2010). To the matter of introduction to the State Pharmacopoeia of Ukraine of the monograph «Thyme». Farmakom, 4, 31-38.

[9] Markovych, I. I., Paska, M. Z. (2015). Impact of raw materials on the fatty acid profile changes of semi-smoked sausages. Naukovyi visnyk Lvivskoho natsionalnoho universytetu veterynarnoi medytsyny ta biotekhnolohiyi imeni S. Z. Gzhytskoho, 4 (64), 71-75.

[10] Paska, M., Simonova, I., Galuch, B., Basarab, I., Masliichuk, O. (2017). Toxic elements in lentil, thyme and juniper in the composition of semi-smoked sausages using the method of atomic-absorption spectrometry with atomization in flame. EUREKA: Life Sciences, 4, 35-42. doi: https://doi.org/10.21303/25045695.2017.00388

[11] Mozhzhevel'nik - ohotnich'ya pryanost' (2010). Myasnoe delo, 7, 33.

\title{
DETERMINATION METHODS OF DEFROSTED PROTEIN-VEGETABLE MIXTURES PARAMETERS DEVELOPMENT
}

\author{
Sergii Tsygankov \\ Institute of Food Biotechnology and Genomics NAS of Ukraine \\ 2A Osypovskoho str., Kyiv, Ukraine, 04123 \\ tsygankov.iht@gmail.com \\ Viktor Ushkarenko \\ Department of Agriculture \\ Kherson State Agricultural University \\ 23 Stretenskaya str., Kherson, Ukraine, 73000 \\ Ushkarenkov@gmail.com \\ Olena Grek \\ Department of milk and dairy products technology \\ National University of Food Technologies \\ 68 Volodymyrska str., Kyiv, Ukraine, 03680 \\ grek.nupt@gmail.com \\ Alla Tymchuk \\ Department of milk and dairy products technology \\ National University of Food Technologies \\ 68 Volodymyrska str., Kyiv, Ukraine, 03680 \\ 589112@ukr.net \\ Inna Popova \\ Department of Food Chemistry \\ National University of Food Technologies \\ 68 Volodymyrska str., Kyiv, Ukraine, 03680 \\ ivpopova@bigmir.net \\ Natalia Chepel \\ Department ofFood Technologies \\ Kyiv Cooperative Institute of Business and Law \\ 18 Lomonosova str., Kyiv, Ukraine, 03022 \\ natachepel25@gmail.com

